International Journal of Human Ecology

http://dx.doi.org/10.6115/ijhe.2012.13.2.101

SORA KIM Sunchon National University

EUN-JIN HAN ${ }^{\star}$ Sunchon National University

\title{
Content Analysis of Food Advertising Directed at Korean Children ${ }^{\dagger}$
}

Children have become the target of intense and specialized food advertising efforts. This study examines the content of TV food advertising and discussed possible concerns from the perspective of children. A total of 102 ads were collected from two cable networks aimed at children. Most of the food ads used emotional appeals and did not provide information clues such as nutrition values. Ads with high sales pressure and celebrity endorsements appeared frequently and the ads for snack foods and high-carbohydrate bakery products were dominant. Understanding food ads can be a significant indicator to establish the orientation of consumer ad education and build educational programs appropriate for children. The issue that appears conspicuous in child targeted advertising and marketing is the childhood obesity and food advertising relation; subsequently, there is a need to evolve advertising that targets children into a positive educational information source.

\section{Issues of Food Advertising}

With the criticism that carbonated beverages and fast food add to children's obesity, the World Health

\footnotetext{
${ }^{\dagger}$ This paper was supported by Sunchon National University Research Fund in 2010.

Corresponding author: Assistant Professor, Division of Social Welfare, Sunchon National University, 255 Jungang-ro, Sunchon, Jeollanam-do, R.O. Korea (srkim@sunchon.ac.kr)

${ }^{*}$ Senior student, Dept. of Environmental Education Sunchon National University, 255 Jungang-ro, Sunchon, Jeollanam-do, R.O. Korea (eunjin6627@naver.com)
}

Key Words: food advertising, informativeness, children, healthfulness
Organization (WHO) and governments have requested that the food-and-beverage industry take proactive measures. Leading beverage enterprises Coca-Cola and Pepsi have suspended all global advertising that targets children under 12 years old (Warren, Wicks, Wicks, Fosu, \& Chung, 2007). In addition, soda advertising that targets children as started to disappear from the media (television, the Internet and movies) (Roberts \& Pattigrew, 2007). The Special Act on Children Food Safety Management enforcement ordinance was passed in Korea on January $19^{\text {th }} 2010$. The ordinance bans TV, cable, and satellite advertising from 5-7 PM. on high calorie and low nutrition foods that contain excessive amounts of sugar, fat and sodium over a certain criteria. It also bans mid-program ads that target children (Today Korea, 2010). The Korea Food and Drug Administration (KFDA) opened a high calorie - low nutrition food list to the public (KFDA, 2009).

Children's TV viewing time is a factor for increased advertising exposure as well. The Los Angeles Times reported that the TV viewing time of American preschoolers aged 2-5 is more than 32 hours a week, and TV viewing time for American children aged 6-11 is 28 hours a week, which is the highest on record according to a Nielsen Media Research survey (Gold, 2009).

In 2007, Washington University in the U.S. reported that the increase of infants and children's TV viewing time could be an obstacle for language 
development skills and a potential trigger of obesity. The study emphasized that TV viewing interferes with "play" and "reading" enhancing cognitive abilities. Some American psychologists and medical specialists contend that if one understands a child's cognitive development process, the label of "Beneficial TV Program" is moot. The Campaign for a CommercialFree Childhood was started in Europe by NGOs (initiated by Germany); however, American civic groups have recently increased the pace in raising the collective concerns over media advertising intent (Ibid).

TV programming can perform a role as a useful public information source; however, advertising can be deceptive because it can cause a bigger consumption problem due to the ease of contact. Children (who have limited information processing ability) can be affected by commercial ads more than adults (Alwitt, Anderson, Lorch, \& Levin, 1980). If children's advertising focuses only on the commercial purposes and hides the negative characteristics by not clarifying detailed information, it can arouse mental unhappiness in a child after purchase.

Fast-food enterprises spend huge amounts on advertising to stimulate a children's desire to buy. By changing a child's favorite toy series, they have developed a process by which children might urge their parents to go to the stores repeatedly to purchase toys. Likewise, fast-food companies are passionate over ads that target children because a habitual taste in the childhood is an important longterm marketing strategy. If one gets accustomed to tasting sweet, salty, and fatty food growing up, one hardly changes their tastes in adulthood. According to the data (Gamble and Coutugna, 1999; Roberts and Pattigrew, 2007; Society for People Keeping the Next Generation, 2004), one reason why child obesity is increasing rapidly is the exposure to ads, especially in the field of food.

\section{Purpose of Study}

It often is suggested on the negative side that ads that target children give too much weight to commercial persuasion and stimulate children's reckless consumer sentiment; in addition, they are liable to arouse conflict between parents and children, harm health, or safety (Kelly, 1974). This study examines the contents of food advertising directed at children and discusses possible concerns from the perspective of children. The emphasis of this study is on food advertising practices in Korea. Through a content analysis of food advertisements, it could be expected to discuss a better direction where children's advertising becomes a useful educational information source. Based on this, we provide suggestions for children to utilize food advertising properly as an information source, further suggest a method in which broadcasting ads may perform a persuasive commercial advertising function and informationproviding function as well as a socially responsible educational function.

The conspicuous issue in child targeted advertising and marketing is the relation between childhood obesity and food advertising; subsequently, we examine the actual situation of food advertising. It is thought that such study is important to provide the ideas to regulate child-targeting ads.

\section{LITERATURE REVIEW}

\section{Characteristics of Child Consumers}

The influence of child consumers has increased in Korea. Childhood is a significant stage of socialization for consumer socialization. Children have limited decision making capability and seldom recognize the channel from advertising awareness on product purchasing; in addition, they are economically dependent on parents and have restricted real purchasing power. Children are deemed to be an active consumption bracket as well as an important influence on family purchase decision making; subsequently, they have become the targets of marketing strategy (Park, 2004). Each enterprise entices the consumer needs of children through a variety of promotional strategies that target children, especially active sales activities through various media advertising that aggressively enlarges the market where each enterprise attempts to expand its territory through broadcasting media ads with easy access. Of importance is whether children can distinguish commercial ads from broadcast programs 
and understand the intention of commercials. Research has shown that a child only begins to have a basic understanding of the purpose of advertising at age 8-10; subsequently, at age 12 that the child comes to understand advertising as the whole. Most children retain a limited ability to process advertising information in the cognitive development stage (according to their age) and they can be more profoundly affected by exposure to commercial ads (Alwitt, Anderson, Lorch,, \& Levin, 1980).

Enterprises regard children as primary consumers from three angles (Son, 1999; Merskin, 2002; park, 2004; Schor, 2005). First, children are the consumers that form the existing market for varied goods and services and they have the money to purchase desired goods. Second, children are the consumers for a future market and childhood is the time when preferences and trademark recognition is formed as future consumers. Third, children are influential consumers the effect purchases by parents.

Child consumers have the following properties in modern society (Rhee \& Park, 1990). First, there is increased ability for children to spend freely. Second, double income parents tend to be more receptive to the impulsive desires of children; therefore, there is little control of the desire of child consumers towards consumption. Third, modern child consumers are exceedingly exposed to a mass media that stimulates consumption needs. They are significantly affected by TV, which has a strong influence in children's society. Child consumers reflect their own opinion when purchasing products and directly and indirectly influence household purchase behavior; subsequently, it is salient for advertisers to be aware of the potential for commercial messages to undermine healthy eating behavior.

\section{Children and Advertising}

Juliet Schor has studied American consumer culture and argues that advertising may cause a problem more than the intensification of sentiment by child consumers. She explained in her book Born to Buy that children exceedingly exposed to consumer culture have more serious mental anxiety, depression, and a degeneration of the parental relation as well as other children (Schor, 2005).
When considering the characteristics of child consumers, there is insufficient consumer education to improve the abilities of child consumers. Child consumers who are the sales targets of marketers do not understand the complexities of the market. They have not developed a cognitive defense against advertising or recognize the values of the goods due to the abundance of material goods provided by continuous economic growth (Hyman, Tansey, \& Clark, 1994). The following is a description on the negative effect of advertising on children (Society for People Keeping the Next Generation, 2004).

- It renders children unable to satisfy themselves, creates the desires and needs parents cannot accept, and thereby builds tension in the family or does harm to children's character building.

- It overemphasizes materialistic values and enhances the level of children's aspiration to consume high-priced toys, children's supplies, clothes, etc.

- It stimulates excessive consumption of food harmful to children's health, such as candy, chocolate, or ice cream (for example, leading to obesity or decayed teeth, etc.).

- The use of jargon, slang, and buzzwords in advertising can be a bottleneck in emotional development and sound use of language.

- The excessive expectation and imagination about the products appearing in advertising give birth to disappointment.

These negative functions derive from the characteristics of ads that target children. In order for commercial advertising to play its role fully as the purchase motivator, we need to replace current commercial advertising and protect children from commercials. In the case of the USA or England, a thorough deliberation in regards to ads that target children is being conducted by self-regulatory advertising organizations (Merskin, 2002). Sweden and Norway ban all TV commercials that target children under 12; in addition, Sweden is making diplomatic efforts for all EU countries to accept the advertising ban policy. Korean regulations on ads that target children are not concrete or detailed; subsequently, measures to correct this situation are 
required (Nam \& Yeo, 2005).

Especially from the health perspective of children, the effects of eating habits on child obesity have been discussed in numerous literature. Calorierich drinks and foods are readily available to children. The consumption of sugar-laden soft drinks may contribute to childhood obesity. In a previous study, the likelihood of obesity increased 1.6 times for every additional soft drink consumed per day (Kerr, 2005). Calorie-dense - prepared snacks are available in many places frequented by children. Childhood obesity has become more prevalent and snack vending machine locations in schools have been regulated in a small number of localities. Eating at fast food restaurants is very common among young people, with $75 \%$ of primary students consuming fast food in a given week (French, Story, Neumark-Sztainer, Fulkerson, Hannan, 2001), The fast food industry is also at fault for the rise in child obesity. This industry spends about $\$ 4.2$ billion on advertisements aimed at children. McDonald's alone has thirteen websites that are viewed by children and teenagers each month (Tracy, 2010).

Ads that target children are a useful means to help the understanding of economics as well as to aid in child consumer socialization. Therefore, advertising performs its function perfectly when it fully performs an educational function to fulfill a social obligation as well as a persuasive function and an information-providing function. For this purpose, it is preferable to develop the environment of advertising regulations to address the concerns of contemporary society.

\section{Situations of Advertising Regulations}

Child consumers are limited in information processing due to their immature cognitive ability and they can more strongly be affected by advertising than adults. Children are unable to have reasonable decision-making power and for advertising to play its proper role for child consumers it needs to make up for the proper function of existing media ads and new media ads and sublate the reverse ads and protect children (Kelly, 1974).
Many countries regulate ads that target children to prevent children becoming a means to secure commercial profits. In 1991, Sweden enacted the Radio and TV Related Act that banned all ads from being run before or after children's programs. Before 9 PM, ads the targeted children under 12 (such as for toys and fast food) are totally banned, and after 9 PM, they can be televised only towards parents. Australia prohibits advertising during preschooler program broadcast times (Nam \& Yeo, 2005). America and England recognize the freedom to advertise as a constitutional right and they consider the proper function factors of ads that will develop self-regulatory regulations instead of enforcing regulations. In the USA, self-regulatory guidelines on child advertising are limited. For example, they stipulate that ads should not induce children towards excessive imagination or sex role innuendo. In addition, they recommend that children learn proper behavior through advertising and a desirable parent-child relationship that relays information using correct and proper language. They also recommend not embellishing the real size of the products or exaggerating the function for children to have excessive expectations (National Advertising Review Unit, 2009). The American Children's Advertising Review Unit (CARU) suggested eight basic principles on ads that target children as follows: 1) The limited capacity of children to evaluate information dictates that advertisers are responsible for protecting young children. 2) Advertising should be neither deceptive nor unfair. 3) Advertising should have adequate substantiation for objective advertising claims. 4) Advertisers should not create unrealistic expectations for their products. 5) Advertised products should be appropriate for children. 6) Advertisers should provide examples of positive and beneficial social behavior. 7) Advertising should avoid social stereotyping. 8) Advertisers should contribute to this parent-child relationship in a constructive manner.

In the case of Korea, the basic laws and regulations to control commercial ads that target children and teenagers are found in the Youth Protection Act and the Broadcasting Act; in addition, concrete regulations are presented in the Rules 
Regarding Broadcast Deliberation. In an Article 24 on Children \& Youth of the newly-amended Provisions of Broadcast Advertising Deliberation, the examples related to food advertising are follows as (Korea Communications Standards Commission, 2010).

- TV Commercials shall not be harmful for children's and teenager's nature, emotions, and value aspect.

- TV Commercials shall not contain the following expressions in order to protect children:

- Expressions that children may feel inferior or be teased by not owning the product

- Expressions that stimulates a child's impulse to purchase or force parents to purchase the product

- Expressions that stir up a child's gambling spirit

- Expressions that induce children to stay in a dangerous area or to behave in a dangerous way

- Expressions that block children from having healthy meal habits

- Subordinate products or gifts shall not be emphasized other than the main item in the commercials that target children.

Other than the above, the Broadcasting Committee also limits the baiting type of commercials. TV commercials shall not induce people to purchase luxury products or services by providing the message that they provide products or services that are not for the purpose of sales. Rules for broadcasting inspections contain regulations in regards to children and teenagers; however, there still is a requirement to establish regulations that consider the effect of broadcasting and advertising characteristics on children. The establishment of specific advertising policies to protect children, advertisement education, and specific instructions for commercials that target children are considered priorities. A comprehensive human rights approach is required for commercials that target children (including the health rights of children). Various approaches are also required such as advertisement education in schools as well as increased level of restrictions (Grainger, Senauer, \& Runge, 2007).

In the U.S. and England, the social responsibility of advertisements is emphasized based on a significant understanding of child development, such as children's imitation and studying behavior. However, only formal regulations are included in Korea and the standards on children's safety and protection are unclear; in addition, the contributions of commercials towards a child's personal and social growth are totally ignored.

\section{METHOD}

Data Collection

This study collected food ads on child-targeting cable channels from Monday through Friday morning time (9:00-12:00). A total of 102 food advertisements were collected from child-targeting cable channels aired in the afternoon (4:00-7:00) for two weeks in August 2011 and two weeks in January 2012. The two cable networks aimed at children with highest the ratings were selected. From the two channels, the 120 hours of children's television programs sampled 316 commercials. These advertisements included 102 advertisements for food products. The morning programs are chiefly for preschoolers, while after $4 \mathrm{PM}$ is primary-school children's main viewing time. Children of various age brackets are exposed to many ads. As for food ads, we included ads only for children as well as those that targeted mothers and children viewing TV together. Though the marketing targets were not children, ads were easily seen by children. The collect did ads were coded by two authors individually; then the ads that did not conform were discussed and recoded. Coding items for the analysis were selected and amended based on "The Guideline of Children's Advertising Review Unit" of the USA and "The Rules on Broadcast Advertising Deliberation" of the Korea Communications Commission. In the coding process, two researchers watched the ads individually three times, first separately viewing all the advertisements from the coding items, then coding and watching the ads twice more.

\section{Analysis Method}

We analyzed the content of the food ads collected 
Table 1. Rationales for the Seven Items of the Content Analysis

\begin{tabular}{|c|c|c|}
\hline Item & National Advertising Review Unit (2009) & Korea Provisions of Broadcast Advertising Deliberation (2010) \\
\hline Informativeness & $\begin{array}{l}\text { Advertising should have adequate substantiation for } \\
\text { objective advertising claims }\end{array}$ & \\
\hline Sales Pressure & $\begin{array}{l}\text { Advertising should not urge children to ask parents or } \\
\text { others to buy the products. }\end{array}$ & $\begin{array}{l}\text { TV commercials should not contain the expression that } \\
\text { stimulates children's impulse purchasing or forces par- } \\
\text { ents to purchase the product. }\end{array}$ \\
\hline Endorsement & $\begin{array}{l}\text { The mere appearance of celebrity or authority figure } \\
\text { with product could alter a child's perception of the } \\
\text { product. }\end{array}$ & \\
\hline Presentation & $\begin{array}{l}\text { Advertisers should contribute to parent-child relation- } \\
\text { ship in a constructive manner. }\end{array}$ & \\
\hline Sales Promotion & $\begin{array}{l}\text { Advertisers should recognize that their use of premi- } \\
\text { ums and contests has the potential to enhance the } \\
\text { appeal of their products to children. }\end{array}$ & $\begin{array}{l}\text { TV commercials should not contain the expression that } \\
\text { stir up a child's gambling habit. }\end{array}$ \\
\hline Program Character & $\begin{array}{l}\text { Program personalities should not be used to advertise } \\
\text { products directed to children under } 12 \text { years of age }\end{array}$ & \\
\hline Healthfulness of foods & & $\begin{array}{l}\text { TV commercials should not contain the expression that } \\
\text { block children from having healthy meal habits. }\end{array}$ \\
\hline
\end{tabular}

through the result of coding. Based on the guidelines and the regulations synthesized from the US Children's Advertising Review Unit and Korea Provisions of Broadcast Advertising Deliberation, we executed the assessment of food advertising for a content analysis. Table 1 shows the rationales for the seven items to assess food ads.

1. Informativeness: In advertising, do they give sufficient information on foods, especially nutritional information? Did they exclude information unfavorable to the seller, or reduce it? Resnik and Stern (1977) created a classification system that segmented 14 information clues - price/value, quality, performance, component/content, purchase guide, special provision, taste, nutrition, packing, guarantee, safety, survey of independent agency, self-survey of an enterprise, and new ideas. The content clue of information appearing in advertising is the information content; in addition, informativeness can be higher as the content clues of information appearing in advertising are abundant. Resnik and Stern (1977)'s 14 information clues have been used to assess traditional advertising channels that include print, radio, TV, and newspapers. Among these 14 items, price/value, performance, component/contents were frequently used in TV advertisements; however, the performance clue is not applicable for most of food advertisements and was excluded in favor of analysis that included nutrition clues based on its importance in food products. Among the 14 information clues suggested by Resnik and Stern (1977), nutrition values, price and component/ content can be adopted for information clues for children's food advertising. In this analysis, it was considered informative if the advertisement includes at least one clue out of three information clues that are necessary foods for children.

2. Sales Pressure: Did they force children to purchase the product, or describe it as if the ownership of the product would cause a big change? Did they suggest or emphasize the phone number inducing the purchase? It was considered a sales pressure ad if the ad includes messages that force children to purchase the product.

3. Endorsement: Did they emphasize a child's favorite celebrity or character and is the explanation about the product sufficient? According to the Children's Advertising Review Unit guidelines (National Advertising Review Unit, 2009), the mere appearance of celebrity or authority figure with the product could alter a child's perception of the product. A personal endorser must take great care to avoid a false impression that the use of the product is enhanced by the celebrity's performance. If the celebrity endorses food products, it was classified as an endorsement ad. 
4. Presentation: Is the parents' role or family relation suggested properly in advertising? It was regarded as a presentation ad if the ad presents parental roles in a socially desirable manner.

5. Sales Promotion: Did they lure children with bait goods or emphasize the event? It was considered as a sales promotion ad if the ad includes sales promotion with a special gift.

6. Program Character: Can the appearance of a popular child hero or character arouse confusion between advertising and programs? TV advertisements might include animal characters such as Barney the Dinosaur and action figures like Spiderman. These kinds of characters could endorse food products in TV advertisements. Children's Advertising Review Unit's guidelines emphasize that children may have difficulty to distinguish between program/editorial content and advertising. Thus, program personalities should not be used to advertise products directed at children less than 12 years of age (National Advertising Review Unit, 2009). It was considered as a program character ad in an animal character or an action figure was used in a food advertisement.

7. Healthfulness of Foods: Is the advertised product harmful to children? To examine the distribution of advertised food products, we classified advertised food products based on the Food Balance Wheels (Korean Nutrition Association, 2010). For the healthfulness of advertised food products, high calorie foods with low nutritional values in advertisements are summarized based on the nutritional standards of the Special Act on Safe Food for Children (KFDA, 2012). This analysis has been provided to understand the problems that food ads may cause and protect children. Of the above items, informativeness and healthfulness are especially connected to the health behavior of children (Society for People Keeping the Next Generation, 2004).

\section{RESULTS AND DISCUSSION}

Here we suggested the result of the analysis on 102 food ads that can be exposed to children through child-targeting programs and broadcast channels. Figure 1 shows 42 ads (41.2\%) are in the cereal and

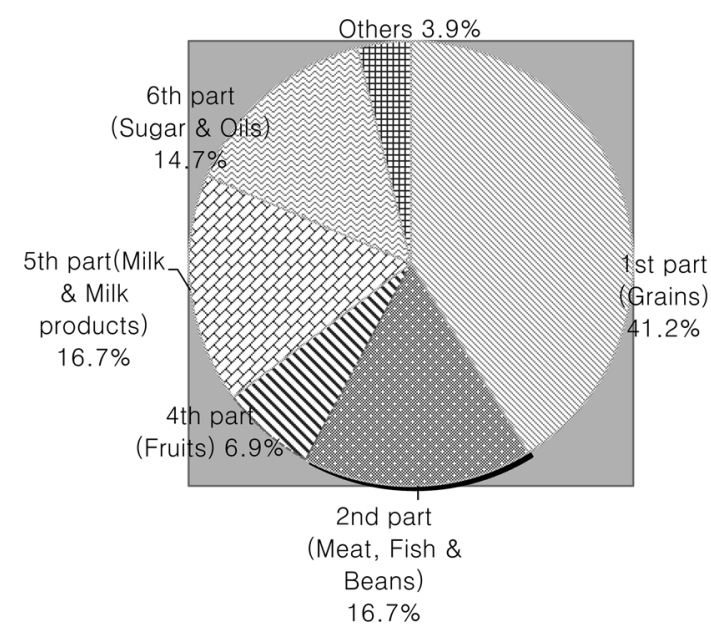

Figure 1 Food Balance Wheels within Ads.

starch category. Among these, four were cereal products; other products were candy, pizza, and Chinese noodles. A total of 7 ads (6.9\%) were for fruits, with 6 being orange juice and one grape juice; however, no vegetables were shown in the advertisements. A total of 17 ads were on the second part and most of them were for chicken (12) and the rest were for meat, bean curd, and eggs. Ice cream was advertised in 12 ads (11.8\%); dairy product ads (that included natural yogurt) appeared all in 17 ads (16.7\%) and milk in only two. There were many carbonated drinks and chocolate ads, with 15 of them $(14.7 \%)$ on the $5^{\text {th }}$ level. The advertising of sugars required a limited intake due to decayed teeth and obesity, often appeared. Of the other 4 ads, curry, not listed on the Food Balance Wheel was deemed to belong to seasoning items. In addition, there were three family restaurant enterprise ads. The composition of the food appearing in advertising is presented in the following circle chart. Generally, the ads of snack foods and bakery products that contain many carbohydrates were dominant and it fails to help children sue varied foods under these conditions.

As suggested in the method of analysis, we discuss it according to seven subjects and diagnose the problems. Table 2 presents the frequency results.

$$
\text { Informativeness of Advertising }
$$

The most important information in food ads relates 
Table 2. Frequency Results of Advertisements $(N=102)$

\begin{tabular}{llll}
\hline \multicolumn{1}{c}{ Item } & \multicolumn{2}{c}{ Frequency (\%) } \\
\hline Informativeness & Nutritional Values & 14(34.1) \\
& & $\begin{array}{l}\text { Component/Content } \\
\text { Price }\end{array}$ & $\begin{array}{c}25(61.0) \\
2(4.9)\end{array}$ \\
\hline Sales Pressure & $30(29.4)$ & \\
Endorsement & $53(52.0)$ & \\
Presentation & $12(11.8)$ & \\
Sales Promotion & $16(15.7)$ & \\
Program Character & $16(15.7)$ & \\
\hline
\end{tabular}

to taste, nutrition, components, and safety . Recently, the advertising trends are oriented towards emotion and providing information clues to waive advertising repulsion. Of the surveyed ads, 41 ads (40.2\%) provided objective information clues (Table 2). Of the 41 ads that presented information, only 14 ads (34.1\%) presented specific nutritional information (such as calcium supplements and vitamins). Except these 14 advertisements, the nutritional information provided contained ambiguous information that mislead children on carbonated drinks like "fresh real fruit juice 11\%," "100\% acid natural drink," and "colorless sugar fragrance". For children, $11 \%$ real fruit juices can be recognized as healthful drinks. Children might misunderstand the meaning of $100 \%$ acid natural drink. This could indicate other food additives are never mixed.

With the appearance of commercial jingles accustomed to the ear or cartoon characters, ice cream ads emphasized only the side of "fun" or the ads of high class, and cake that employed the concept of Christmas or lovers, and friendship, are typical examples of image ads. These types of ads do not contain any information on the taste of the product, price, SSP (Special Sales Point), and nutritional information. In addition, even if they contain information in regards to the product, it was nothing more than extremely superficial information like "flavor," or "added seafood" in many cases.

\section{Sales Pressure}

The most important advertising function for consumers is "information transfer" that facilitates information on the product's attributes and helps in selection. However, it is true that a persuasive function is emphasized more in the marketing side than the information transfer function. Furthermore, ads that target children (and contain selling pressure) can trigger excessive consumption and impulse buying. Exaggerated and superlative expressions such as "every day want to eat," "entirely new like us," "master the world," "ice cream first place," and "not melting lifelong" are influences children should avoid. In addition, direct persuasion often appears as well in such expressions as "To Slug Year 2011," "Too Open-Hearted, and "Call Me Again". A total of 30 ads contained selling pressure messages when it came to ads that targeted children. Most of these 30 ads contained superlative expressions not verified by fact and induced children to consume in order to maintain an image. Especially, in case of deliverable products such as chicken or pizza, there were 18 ads (17.6\%) for direct sales and toll-free phone numbers. The provision of toll-free phone numbers can suggest that children can make the purchase without parental consent.

\section{Endorsement}

Celebrated entertainers appeared in $53(52.0 \%)$ of the analyzed ads, with most of them singers and TV actors who are very popular among teenagers. They tried to jump on the popularity bandwagon of ad models; therefore, most of them were image ads without clear product information; in addition, the products themselves were high calorie and high-fat foods. Popular children's celebrities appeared in delivery products of chicken or pizza and products such as doughnuts, ice cream, and cake. Also, children's idols were used as advertising models in products like coffee drink and instant noodles. This situation has resulted in a problem because these products are connected with misleading information. In many cases, they contained factors to bring about a negative effect on children, such as youth giving rough talk to seniors (undesirable attitude), the emphasis of toll-free numbers, and the relation between the product and victory in a basketball match (expecting the change due to the ownership of goods); subsequently, they were excessively weighted in the persuasive function instead of the 
information-relaying function.

\section{Presentations}

Table 1 shows that only 12 ads (11.8\%) had parents or described parental roles. In most ads, an adult model or a child model appeared exclusively; only a few ads had the family appear. Examples are a scene in which a father and son are taking bath merrily together in a juice advertising, a case where one stresses a two-year-old's milk habit in a milk ad, a scene in which mom wakes up a child to feed them cereal for breakfast, and another where all the family dine at a family restaurant. Solitary eating is prevalent, with images of food being consumed alone in eating situations. Family meals were not a common type of eating situation. The family eating situation might be related to eating more fruits and vegetables and less soft drinks (American Dietetic Association, 2004).

Dietary habits are significantly affected by the family; therefore, the relation between parents and children needs to be stressed in the ads. About 37 ads that target children described improper language expressions or behavior; these included the expression "completely absurd" or expressed the delight of fast food, stressing no waiting and easy eating, the appearance of a youth using impolite language to an old person in a snack ad. All of these presentations show undesirable language, unsafe behavior, or improper dietary habits for children. For example, some ads included new-coined abbreviations and jargon or snack foods were depicted as meal substitutes. One ad showed children with no knee pads or a helmet while roller-skating.

\section{Sales Promotion}

After the Korea Communications Commission announced strict regulations on TV commercials, the ads in which fast food stores induce children with a bait commodity decreased. In this survey, there were two ads that offered Christmas presents after purchasing a cake from a bakery company. There were $16(15.7 \%)$ event ads in which purchasing products created an opportunity to subscribe to an event and created a prize-winning expectation in children. The event period or conditions tends to be suggested quickly in small print that children may not be able to read. The ads with sales promotions demonstrated a heavy reliance on purchase inducements such as free toys. The offered inducements included action figures, toy cars, plastic jewelry, teddy bears, and mini books.

\section{Program Character}

While the $52.0 \%$ of ads with well-known celebrities, the appearance of animation program characters occurred in 16 ads (15.7\%). A popular cartoon character mainly targets preschoolers and lowergrade children; however, famous entertainers can appeal to children and youth. In many cases, the characters that appeared in the ads for snacks, cereals, or beverages come in a brand name of a product that is familiar to children. The prevalence of animated spokespeople is (not surprising as one previous study suggests of animation characters ) a highly effective way to engage young children as it provides perceptual salience, no need to overcome memory storage, and unhindered retrieval difficulties (Neeley \& Schumann, 2004).

\section{Healthiness of Foods}

Are the products appearing in advertising healthful food to be recommendable to children? Based on the nutritional standards of the Special Act on Safe Food for Children (KFDA, 2012), advertisements of high calorie foods with low nutritional values in the analyzed advertisements are as follows: 17 ads for Snack foods (16.7\%), 17 ads for soft drinks (16.7\%), 12 ads for frozen dessert (11.8\%), 9 ads for pizza (8.8\%), 5 ads for bakery products (4.9\%), 4 ads for ramen (3.9\%) and 2 ads for chocolate (1.9\%). A total of $64.7 \%$ of advertised foods were high calorie foods with low nutritional values. This might cause health concerns for food advertisements that targeted children from the perspective of childhood obesity and nutritional balance,.

\section{CONCLUSION}

Examining the state of Korean food ads is necessary to protect children from harmful advertising, along 
with suggesting nutritional standards to assist in proper food selection and a healthy dietary life. We examined the state of TV advertising at a time when the control over child-targeting food ads intensified. We need to draw attention to varied nutritional intake and escape from ads centered on high calorie, low nutrition food centered advertising, and carbohydrate-centered ads.

Some concerns have arisen on the educational side of food advertising. Undesirable attitude and improper behavior expressions often appear, and we especially need to pay attention to the conditions where the role of ad models may influence children. Negative aspects also were seen in the information functional phase of advertising. Most of them were emotional appealing ads that did not provide certain information clues and cases that suggested ambiguous nutritional information. High sales pressure ads appeared frequently as well. Using the highest and the longest type, they urged children to purchase goods and attempted to enhance brand royalty.

In this study, we examined what type of food ads Korean children see. The educational phase of advertising and the ampleness of information can use basic guidelines related to child consumer education and consumer information in the future. Present advertisements directed towards children were likely to use emotional appeals and not provide certain information clues such as nutrition values. Ads with high sales pressure and celebrity endorsements appeared frequently; however, ads that depicted parental roles were the least appearing ads. Generally, advertisements directed at children are not likely to follow the guidelines of sales pressure, endorsements, and parental presentation. More problems might be that snack food ads, bakery products, and frozen desserts that contain many carbohydrates and sugars were dominant.

Rather than emotional appeals, food ads could be utilized as a nutritional and health information channel. For example, shared family eating situation in ads might include healthy eating behavior such as an increased consumption of fruit and vegetables. Further, an advertising campaign aimed at children would be effective for healthy eating education. Children might gain ideas about the importance of healthy meals from advertisements with a child's favorite animated characters. Especially, important food groups in each developmental stage could be considered for TV program time. For example, for preschoolers and younger children without permanent teething, it would be helpful to provide information on foods that cause decayed teeth.

This study also examined the possibility of misleading advertising from a child's healthy eating behavior and suggested the necessity of advertising education. Children could misunderstand the meaning of healthy eating and ignore the importance of nutritional food values. The emphasis on the pleasure of eating in emotional appeal ads and prizes in sales promotion ads might make children misunderstand nutritional food values and their health benefits.

The contents of ads that target children (or the method suggested) is more specialized and complicated as the information that consumers demand becomes diverse and specialized. In these situations, understanding food ads can be a significant guideline to establish the orientation of consumer ad education and build educational programs appropriate to children. It will be used as an instrument for practical child consumer education so that a sponsor earns consumer trust and that the consumer receives necessary information through advertising. This research is to help protect children from deceptive ads and pursue consumer satisfaction.

\section{REFERENCES}

Alwitt, L. F., Anderson, D. R., Lorch, E. P., \& Levin, S. R. (1980). Preschool children's visual attention to attributes of television. Human Communication Research, $7(1), 43-58$.

American Dietetic Association (2004). Position of the American Dietetic Association: dietary guidance for healthy children ages 2 to 11 years, Journal of the American Dietetic Association, 104, 660-677.

Frence, S. A., Story, M., Neumark-Sztainer, D., Fulkerson, J. A., Hanna, P. (2001). Fast food restaurant use among adolescents: associates with nutrient 
intake, food choices and behavioral and psychological variables, International Journal of Obesity, 25(12), 1823-1833.

Gold, M. (2009). Kids watch more than a day of a TV each week. LA Times. Retrieved May 9, 2012. from http://articles.latimes.com/2009/oct/27/entertainment/ et-kids-tv27.

Granger, C., Senauer, B., \& Runge, C. F. (2007). Nutritional improvements and student food choices in a school lunch program. Journal of Consumer Affairs, 41(2), 265-284.

Gamble, M. \& Cotugna (1999). A quarter century of TV food advertising targeted at children. American Journal of Health Behavior, 23(4), 261-267.

Hyman, M. R., Tansey, R., \& Clark, J. W. (1994). Research on advertising ethics: Past, present, and future, Journal of Advertising, 23(3), 5-15.

Kelly, J. P. (1974). The effects of cognitive development on children's responses to television advertising, Journal of Business Research, 2(4), 409-419.

Kerr, J. J. (2005). Prevention of childhood obesity by reducing soft drinks. International Journal of Obesity, 29(2), 54-57.

Korea Communications Standards Commission (2010). Provisions of Broadcast Advertising Deliberation.

Korea Food and Drug Administration (2012). Special Act on Safe Food for Children. The National Standards for High-Caloric Foods with Low Nutritional Values.

Retrieved Nov. 21, 2012. From http://kfda.go.kr/jsp/ page/decision.jsp

Korean Nutrition Association (2010). Dietary Reference Intakes for Koreans.

Merskin, D. (2002). Boys will be boys: A Content analysis of gender and race in children's advertisements on the Turner Cartoon Network. Journal of Current Issues and Research in Advertising. 24(1), 5159.

Nam, K., \& Yeo, J. (2005). The Regulation Plan of TV advertising to children consumers: Results from the analysis on the actual condition. The Journal of Home Economics, 43(1), 203-223.

National Advertising Review Council (2009). Self-reg- ulatory program for children's advertising. The Council of Better Business Bureaus, Inc. New York, NY. Neeley, S. M. \& Schumann, D. W. (2004). Using animated spokes-characters in advertising to young children: does increasing attention to advertising necessarily lead to produce preference? Journal of Advertising, 33(3), 7-23.

Park, E. (2004). Korean's consumption psychology: Growing kids market with parental interests. Ad Information, April, 81-86.

Resnik, A., \& Stern, B. L. (1977). An Analysis of information content in television advertising. The Journal of Marketing, 41(1), 50-53.

Rhee, K. \& Park, S. (1990). Children consumer and advertising. Korean Journal of Advertising, 8(3), 5-22.

Roberts, M., \& Pattigrew, S. (2007). A thematic content analysis of children's food advertising, International Journal of Advertising, 26(3), 357-367.

Son, Y. (1999). Kids marketing. Ad Information, October, 66-70.

Tracy, B. (2010). Fast food restaurants not fighting child obesity. CBS News. Nov. 22, 2010.

Retrieved Nov. 19, 2012. from http://www.cbsnews. com/stories/2010/11/08/eveningnews/main7035550.shtml

Schor, J. B. (2005). Born to buy: The commercialized child and the new consumer culture. New York: Simon \& Schuster.

Society for People Keeping the Next Generation (2004). The Problems of fast food advertising. Report on TV advertising targeting children.

Today Korea (2010). No more high caloric-low nutritional food ads on TV for children. Retrieved May 9, 2012. from http://www.todaykorea.co.kr/news/articleView. html?idxno=94617

Warren, R., Wicks, J. L., Wicks, R. H., Fosu, I., \& Chung, D. (2007). Food and beverage advertising to children on U.S. Television. Journalism \& Mass Communication Quarterly, 84(4), 795-810.

Received May 16, 2012

Revised December 16, 2012

Accepted December 17, 2012 